\title{
From the Universal to the National
}

\section{The Question of Language and Writing in Twentieth-Century Korea*}

\author{
Lim HyungTaek \\ Sungkyunkwan University \\ limı67@skku.edu
}

\begin{abstract}
With the advent of western modernity towards the end of the nineteenth century, the Chinese scriptworld deconstructed. This was the greatest transformation to take place in this region in all of its recorded history, for that history began in Chinese script. China, Japan, Vietnam, and Korea all used the Chinese script but used it in different ways. The universal system was developed uniquely in each case in interaction with the vernacular. This paper will examine the ways in which Korea adopted and negotiated with the Universal script and how Chinese writing developed with respect to Korean speech. It will conclude with some observations on the tensions brought to bear on the Chinese scriptworld by nationalization and westernization.
\end{abstract}

\section{Keywords}

Chinese Scriptworld - nationalization - Westernization - Korean National Language

* Translated by Sowon S. Park. Translator's note: This translation is a slightly shortened version of the Korean original, which is a revised and expanded version of the paper presented by the author at the 2015 East Asian Critical Journal Conference held at Lingnan University in Hong Kong on 30-31 May on the theme of “Colonialism in Asia (殖民亞洲)". While the essay refers to texts most of which have not been translated into English, readers need not be familiar with the literature cited in the essay for them to follow the argument. In undertaking the translation of this essay, every attempt was made to preserve the author's tone and style wherever possible. I am greatly indebted to Emeritus Professor Paik Nak-chung (Seoul National University) for his guidance and instruction on earlier versions of the translation. The responsibility for any mistakes that may remain are mine and mine alone. 
The "universal" language as stated in the title refers to the Chinese script system used commonly in East Asia, known in Korea as hanja and hanmum. ${ }^{1}$ Chinese characters were first developed for writing the Chinese languages, or hanyu (漢 語), but they were then adopted by China's neighbouring cultures and used across East Asia as the main system of writing for a millennium. Prior to the twentieth century classical Chinese was the "universal written language" of China, Korea, Japan and Vietnam. The dissolution of the universal Chinese scriptworld launched the age of national scripts and national literatures.

Chinese script was adopted in Korea during the early days of the Period of Three Kingdoms, approximately two thousand years ago; and in Japan at least thirteen hundred years ago as evidenced by the texts, Nihon Shoki (日 本書紀) and Kojiki (古事記). By contrast, Mongols, Turks, and Tibetans did not take up the Chinese writing system, even though they had much closer geopolitical ties with China throughout history. The Chinese scriptworld is not identical with the sinocentric sphere of imperial China. The relations between the Chinese scriptworld and the Chinese empire are multi-layered and complex. (Lim "Center" 301). As I have discussed elsewhere, the precondition for the dissemination of Chinese script is an agricultural foundation for the society (Lim Silhak 23; Lim Korean 56-58).

This cultural sphere was dismantled towards the end of the nineteenth century. In my view, this was the greatest transformation to occur in this region in all of its recorded history - for that history began in Chinese script. With the advent of western modernity, the writing system common to this region was damaged, weakened, and altered.

From a linguistic perspective, the history of East Asia in the twentieth century is one of transition from the Universal to the National. In Korea, its hanmun culture, accumulated through nearly two thousand years' usage of hanmun and hanja, was not only a great legacy but also a historic burden. The challenges posed by the legacy of the hanmun culture are yet to be fully resolved. While the transitional history of language and writing is clearly a linguistic issue, it is not an issue restricted to the linguist: a transition in language and writing systems accompanies a shift in civilization, impacting on every aspect of its culture. Hence a broad historical and cultural perspective is required to do the question justice.

1 Translator's note: The Korean use of Chinese script is classified into the use of hanja (漢字) and hanmun (漢文). The former refers to the characters themselves and the lexical content that they signify while the latter indicates classical Chinese language. 
The much debated issue of script at this transitional point in history is testament to the role script played in the formation of a new order. What was revolutionary was the new and growing perception of the Chinese script as foreign. In Japan and Korea, the belief in the necessity of a written language for one's own nation grew, while faith in the script that had been used for thousands of years weakened. In Vietnam, it was officially abolished. The movement to establish a modern nation-state coincided with these changes. In China the written vernacular Chinese (白話) movement and the Cultural Revolution drastically changed the orthography of Chinese.

While East Asian countries do not share an identical trajectory of modernization, a shared route can nevertheless be traced. One common factor is that the region was subsumed into the West-centric world order; and second, the region was reformed into a modern imperial system. That is to say, Japan colonized Korea, and China became an object of Japanese imperial aggression. Providing an exception to modern West-centric imperialist order, the Japanese empire overturned the traditional sinocentric world. Korea's issues about language and literature in the twentieth century encapsulated the overlay of the two orders, upon which the focus of this essay lies.

Let us first consider the eighteenth century Joseon scholar, Hong Daeyong 洪 大容 (1731-1783). ${ }^{2}$ Hong is now celebrated for his advanced theories on heliocentrism and a spherical earth, an uncommon position to hold in East Asia at that time. Based on his astronomical observations, Hong forwarded skepticism about the prevailing sinocentric beliefs of the time. In his travelogue of China, Damheon yeongi (湛軒燕記), he records his conversations with western and Chinese intellectuals, part of it about scripts. One western intellectual that Hong met was the missionary, Augustin von Hallerstein (1703-1774), also known as Liu Songling (劉松齡), who was working in the observatory of Yenjing. In the travelogue, Hong asks Hallerstein whether Europeans also use Chinese characters to write. Hallerstein's reply is "In my country, we use speech-writing. As we have our own speech, it follows that we have our own writing." Elsewhere a Chinese scholar asks Hong: "Do you have your own writing in your country? ... Do women and children also read?" To which Hong replies, "We do have a separate writing system. The form differs from Manchu characters but the characteris-

2 Translator's note: Korea was the Kingdom of Joseon between 1392 and 1910. 
tics are the same. Women and children do not read but know speech-writing." From this we can infer that hanja and hanmun were regarded as universal writing. One of the scripts of the Qing dynasty, which effectively ruled over Joseon, was Manchu writing. Since hanja and hanmun are considered the universal norm, both Manchu writing and hangul are defined against it and classified as the same.

At that time in Joseon, public and official documents were written in hanmun while the native writing system hangul, or speech-writing, was relegated to the private sphere. No objection to this hierarchy is expressed by Hong. Though he refuted sinocentrism, his critique did not extend to the sinocentric writing culture.

Writing poems and prose in classical Chinese is never easy for the nonChinese speaker. To be literate, Koreans had to undergo intensive training. Hence, Choi Hae 崔滩, a member of the literati in the Goryeo dynasty, once lamented: "We, easterners, even with outstanding talent, must endeavor a hundred or a thousand times more than the Chinese" (Choi vol 2, 27-8). Confronting the task of transcribing Korean language into Chinese script, Koreans devised several methods. This was done by treating Chinese characters both ideographically and phonetically. The first system was hyangchal (鄉札), meaning vernacular letters, the second was idu (吏讀), meaning "official's writing", and the third gugyeol ( $\square$ 訣), a form of glossing Chinese texts for reading in Korean.

The hyangchal method gave a Korean pronunciation of the characters based on syllables associated with the Chinese character and was used to transcribe both the words that came with the Chinese writing system and native Korean words. The association was both phonetic and ideographic and could almost fully realize the syntax and semantics of Korean. Vernacular poetry, hyangga (鄉歌), was composed using this method, with many poets making full use of native Korean words. It is the earliest form of written Korean. These poems are also sometimes known as "Silla songs" as they originated in the Silla dynasty (57 BC-935AD).

The earliest extant hyangga is thought to have appeared in about the sixth century in the Silla dynasty and the last one is from the tenth century during the Goryeo dynasty. They typically consist of four, eight or ten lines and the most popular ten-line poems are structured into four, four, and two-line sections. Important works were written by monks, so Buddhist themes permeate the genre, but the poetic range is wide and many of them are highly lyrical. Twentyfive hyangga survive today, most of them in Samgukyusa. The following is the last line of Seodongyo 薯童謠 (The Song of Seodong) from Samgukyusa (三國 遺事 vol 2): 夜矣卯乙抱遣去如. 
The characters are all Chinese but the writing is in fact a mixed system of ideographic and phonetic transcription of Korean. Translated, the line reads, "what/who (did she) embrace and go to in the night?" This translation is made possible only if one reads each character phonetically as well as ideographically to determine which reading is appropriate. So 夜 (night), and 抱 (embrace) are read for their lexical meaning but the other characters are read phonetically: 矣 as $e$ 에 (in), 印乙 as mweol 뭘 (what), and 去 as ka 가 (go). Here the Chinese characters are given a Korean sound which approximates the sound of the Chinese syllables.

The idu script also represents Korean phonemes through Chinese characters. Idu used symbols alongside Chinese script to indicate Korean grammatical markers. In that sense idu includes hyangchal and gugyeol. In a narrower use of the word, it refers to the system used mainly by the jungin class in the Goreyo dynasty to document public and private texts in Chinese. Idu uses almost the same methods as hyangchal but its uses are more limited to propositions, particle endings and certain technical terms. Moreover, while hyangchal can inscribe Korean syntax and semantics, as we saw in hyangga, idu follows the dictates of Chinese syntax. Hyangchal disappears in the early twelfth century. On the other hand, idu was continuously used in diverse public and private documents till the late nineteenth century for its practical value.

The third system is gugyeol. This is a method that uses the phonetic elements of Chinese characters and simplifies them. As such it corresponds to Japanese kundoku (訓讀) (Saito 87-89). What differentiates them is that gugyeol is divided into a process of hyeonto (懸吐; adding postpositions and ending particles to hanmun texts) and eonhae (颜解; Korean translation of hanmun texts) while kundoku is a single process.

Despite parallels, such as the adoption of Chinese as the official written language and the borrowing of structural and characteristic elements from its script, Korea and Japan's use of Chinese diverge. Korea accepted the Chinese script as the universal lettering and sustained a form of literacy made possible by intensive training and the assistance of the three techniques outlined above. Not having one's own writing system is obviously the primary reason for such a cumbersome system. But that does not satisfactorily explain the culture of Chinese writing in Korea. After the invention of hangul in the fifteenth century, tailored for the Korean language and phonetics, Korean culture continued to revolve around Chinese script. Literature and literary convention did not change much. There can be many reasons but the main one, put simply, is that Korea never wanted to escape from the Chinese scriptworld before the twentieth century. 
In 1908, two years before the annexation of Korea by Japan, the great Korean linguist, Ju Sigyeong (周時經, 1876-1914) proclaimed "Land is the foundation for independence, minjok is the body of independence and language is the spirit of independence" in his book, The Grammar and Phonology of Korea (Gukeomunjeoneumhak, 國語文典音學). He links land, people, and language as the three primary elements for a nation-state, and elevates language as "the spirit of a nation" (國性). The royal road to forming and shaping a nation is "to treasure national language and literature," he argued, promoting the concept of a "national language" (Ju 2).

The idea of a "national language" was modern but its roots can be traced to King Sejong's invention of hangul as set out in Hunmin jeongeum (訓民正 音), literally translated as “Correct Sounds to Instruct the People." In Sejong's manifesto for the establishment of a new alphabet, he declares boldly that "our national language is different from China's." The modern movement for claiming language and literature as "national" began in 1894, the year of three historic incidents that occurred in rapid succession: the Donghak Peasant Revolution, the first Sino-Japanese War and the Gabo Reform. With the defeat of China in the war, the traditional sinocentric order rapidly dissolved. Among the many changes were laws to replace classical Chinese with a "national language." As the testimony of the era, Maecheon yarok by Maechon Hwang Hyeon states: "until 1894, we used to call hanja true letters (黄書) and the eonmun (颜文, vernacular) in Hunmin jeongum (訓民正音) as colloquial letters. However, after 1894, we treasure the latter as our national letters and call the former, hanmun, a foreign script" (Hwang 424).

From the start of the Gabo Reform, hanmun was branded as a foreign script, losing its status as the universal script. Yet, hanja, while being stripped of its position as "true letters," was not completely abolished because one of the Gabo provisions stated that though "national letters are principal for national language, hanja can be supplemented occasionally." This produced what is known as gukhanmun (國漢文, mix of Chinese and hangul) style. Therefore, in the twentieth century, the two styles coexisted to various degrees. Hangul (Korean script) and gukhanmun (mixed Chinese and Korean scripts) coexisted in the pre-modern era too but their position in relation to the other was changed drastically by the Reform.

By having the status of the "national script" conferred on them, hangul and the gukhanmun style were reborn as the twin writing systems of the Korean enlightenment. Gukhanmun was used mainly in the more serious media, like national newspapers, literary and intellectual magazines, books and transla- 
tions of western science, and official textbooks. Pure hangul texts were still for women, so a hierarchy of language along gender lines was maintained in the early twentieth century. If one takes a longer view, one can see that during the Patriotic Enlightenment Movement (1905-10), gukhanmun took over the previous role of Chinese script.

As the Chinese scriptworld gradually dissolved between the late nineteenth century and the twentieth century, a linguistic bridge was required to facilitate the incorporation of modern East Asian nation-states into the western order. The communication between the west and this cultural sphere was not a simple matter of translating existing words into their equivalent. At that time, there were few words that were sufficiently comparable. Of course this posed greater problems for the East Asians as they were scrambling to understand and absorb western knowledge and culture.

In order to assimilate western culture successfully, new words had to be invented. Each of the countries had its own particular trajectory in this regard. Missionaries played a significant role in introducing western culture to this region and their contributions vary from country to country. Overall, it is undeniable that Japan led the way. Japan was the most successful state to transition into the modern era as well as the first. Tokyo became the new centre of the former sinosphere, and it was the very place where a whole new vocabulary for adopting western knowledge was invented. By 1908, the number of foreigners studying in Tokyo exceeded ten thousand Chinese and between four hundred and five hundred Koreans (Kaneko 15). Modern Japan was the training ground for modernity for East Asians. Thus Tokyo found itself as the new centre of East Asia.

The process of coining new words to transfer western civilization and institutions into indigenous language systems was frequently and furiously debated by modern Japanese scholars, who undertook the task of adapting Chinese to the new order. New words were rooted in existing Chinese, but they had to be reconstituted so as to be compatible and understood within a western frame of knowledge. Needless to say, this required a great deal of creativity and innovation. The procedure is defined by the Japanese scholar Koyasu Nobukuni as "re-possession" because Chinese script was regained after being passed through foreign western structures of knowledge for the development of modern Japan. (Koyasu 55).

The differences in adopting Chinese script in Japan and Korea were dis- 
cussed above. Parallel to these differences are the different ways in which Japan and Korea adopted western structures of knowledge. What differentiates them is something that can be called a "pure" system. The development of a "pure" Korean style that flourished in the twentieth century is specific to Korea alone. In Japan, there is no equivalent to Hangul style-there is no Japanese prose style that is free of Chinese script and as widely used as the Hangul style.

Despite branding Chinese script as foreign, the Japanese integrated it into their national language, kokugo (国語), and used mixed style, wakan konkōbun (和漢混交文; Japanese-Chinese mixed style), widely. In the Japanese empire, the presence of the Chinese script in kokugo becomes more dominant than the presence of kana, the Japanese alphabet. This strikes observers as paradoxical. Considering the intensive effort to raise the national language, kokugo, as a key feature of the new imperial ideology in the Japanese Empire (Yi 1996), the proportion between kanji and kana seems to undermine the nationalist ethos. Why do the Japanese publicize wakan konkōbun as the official writing system when it is heavily dominated by Chinese script? The Japanese re-possession of Chinese is attributable to a national orientation and volition. I refer to two books, as representative of two literary societies, Enlightenment History of Chōsen (Chōsen kaikashi, 朝鮮開化史) by Tsuneya Seihuku (恒屋盛服, 18551909), published in 1904 in Tokyo by Tō-a dōbunkai (東亞同文會; Society for Shared Script in East Asia) and the New Dictionary of Common Letters (Dōbun shin jiten, 同文新字典) by Kaneko Gentaro (1853-1942), published in 1909 by Kanji tōitsukai (漢字統一會; Society for Unifying Chinese Script). Both typify the Japanese orientation and volition toward the dongmun (同文; common letter) and hanmun (Chinese).

Tō-a dōbunkai was a Japanese society organized in 1898. Takeuchi Yoshimi (1910-1977) has written about its activities in China (Takeuchi 358-375). Though its activities in Korea have yet to be fully examined, I have written about the imperial nature of its enterprise elsewhere (Lim 2014). Two of its sloganlike doctrines give a succinct summary of their principles: "Work towards the improvement of China and Chōsen (Korea)" and "Act upon the current affairs of China and Chōsen." ${ }^{3}$ They are both linked to the task of "helping Chōsen's independency and developing the Chōsen civilization." (Takeuchi 358-375) These are thinly-veiled justifications of Japan's colonization of Korea.

The Enlightenment History of Chōsen states that "Japanese culture directly advances the peninsula's, and Japan's newly translated words are used widely

3 Translator's note: Chōsen is the Japanese rendition of Joseon (朝鮮), now Korea. 
in Korean politics and learning indicate this." As evidence, the text presents 24 words (Tsuneya $320-321$ ). They are as follows:

Thought: 主義 (ideology, -ism), 目的 (purpose), 自由 (freedom), 權利 (right), 進步 (progress), 開化 (enlightenment).

Social System: 憲法 (constitution), 社會 (society), 演說 (formal speech), 輸出 (export), 輸入 (import), 豫算 (budget), 決算 (balancing accounts), 新聞 (newspapers), 株式 (stock), 會社 (company), 協會 (association), 銀 行 (bank), 用達 (delivery service), 義務 (duty), 運動 (movement),

Science: 植物 (plants), 動物 (animal), 化學 (chemistry).

As the list makes clear, the translated words are actually newly-coined Chinese words. Among them, “freedom 自由” and “society 社會” were words that existed before the advent of western culture but were given a new meaning. "Budget 豫 算”, “balancing account 決算” and “bank 銀行” were completely new inventions. The examples given in the text are just 24 but they represent the cornerstones of western civilization.

What was behind the Japanese policy of disseminating new western concepts in Korea? They are in ideographic Chinese yet there is no denying that they embody the western order of knowledge. The statement by the author, Tsuneya Seifuku, Secretary of Tō-a dōbunkai, provides an explanation: "Unless we do not stop the development of Chōsen by supplying new words to transfer western civilization, Japan's power will not just be for today." (Tsuneya 320-321) Tsuneya Seihuku was also Secretary of Kanji tōitsukai (East Asian Common Literary Society). He had been coming to Korea since 1875 for what was called "colonial business". On the surface this was to "help Chōsen realize its independence and aid its development" (Tsuneya, 320-321) but, as history has proved, what it actually intended was to pave the way for colonization.

The founding of Kanji tōitsukai in April 1907 is significant and demands closer inspection. This was immediately after Japan's victory in the RussoJapanese war. The preface states that "now is the time for closeness between Japan, China and Chōsen as the result of the great war" and to foster closer relations, in education, politics and business. In all aspects the general consensus was that Chinese script was considered indispensable to all relevant threads of society (Isawa 9). Therefore, the policy of providing a unified system of Chinese writing was essential. Though Tō-a dōbunkai and Kanji tōitsukai are called by different names they are executing the same policies and are essentially the same organization.

The president of Kanji tōitsukai was Kaneko Gentarō (1853-1942), who studied at Harvard and served as the minister of agriculture and commerce in Itō 
Hirobumi's cabinet. Itō Hirobumi was himself the official head of the society. This reveals its underlying political nature. The aims of Kanji tōitsukai are found in a Korean document published in the magazine Seou (西友), written by Kaneko and entitled "My View on the Founding of Kanji töitsukai." This article was originally published in the Japanese journal Taiyo (太陽) and translated in Seou but gives little of the political intentions away. However, the activities of Kanji tōitsukai can be traced in the New Dictionary of Common Letters, a dictionary of Chinese characters with the phonetics and the semantics in spoken Chinese, Korean hangul and Japanese kana. It also has a fourth romanized version for defining the sound and meaning. In it we see the aim of unification by means of Chinese script. Among the seven advisors, we see listed Isawa Shuji. Kaneko Gentaro does not appear to have been directly involved in the compilation, merely contributing with a preface. But his preface is a historically significant document. The comparison between various schools in the Chinese classics and western thought is particularly penetrating.

At this time, one of the central debates within Japanese society was whether Japan should abandon Chinese in favour of the Roman alphabet. Kaneko frames his position in the debate with a comparison between eastern and western modes of knowledge. Across the sea, Korea was engulfed in a similar debate. Here the discussion revolved around whether gukhanmun or pure hangul should supersede classical Chinese.

The way in which the two nations dealt with the script question points directly to their respective aspirations and situation. Korea had limited access to global information and current affairs and kept its focus on maintaining its special relationship with China. Thus the issue was dealt with in a passive and defensive manner. The understanding was insular and ideological. Japan, on the other hand, kept a broad, multinational perspective, and was strategic and practical, with a wide information-base from diverse global sources. What really distinguishes the two is that in Japan the two opposing schools of thought on script, the pro-western and the pro-classical Chinese, were already in profound agreement on actively embracing western culture and civilization. Their disagreement hinged merely on which script to use. The pro-western school proposed that "In these times, the obscure Chinese script should be abandoned for the simple roman alphabet." The pro-Chinese school argues for a continuation of the tradition and accumulation of script culture to absorb western knowledge. As they argued:

It hardly needs saying that we must actively absorb western culture. Thus our reliance on the roman alphabet will increase as time goes by. However, to fully ingest, we must thoroughly masticate and digest. Furthermore, 
we must bring the digested western imports to bear on the East Asian continent, to be able to export to both China and Korea, what they culturally lack. Who else is equal to this task?

KANEKO 13

Modern Japan set itself up as the leader of East Asia on the path to westernization. Under the superficial guise of helping under-developed countries, there actually lies a nationalist strategy.

This aim is revealed in the script debates, as when Kaneko claims that Chinese script must be used in East Asia to "promote diplomacy and trade among Japan, China, and Korea" because the Chinese script "provides a competitive advantage for Japan. We have an advantage over western imperialists to dominate this region." He gives case studies in China to demonstrate his thesis. "Those who argue that Chinese script be abolished in these west-centric times in favour of the roman alphabet are proposing that we replace a sharp dagger with the blunt kitchen knife" (Kaneko 9-10). The climax of the argument comes in the following section: "If the three East Asian countries join together as one mind to manage East Asia, westerners will be driven out from our continent in the near future" (9-10).

"Management of East Asia" reverberates with the Japanese imperial propaganda for Pan-Asianism. For the main agent of the so-called management of East Asia was Japan. Pan-Asianism is another way of describing a Japan-centric new Asian order, where slogans announcing mutual benefit and friendship between East Asian countries executed the Japanese imperial agenda in Great East Asia, justifying the invasion of mainland China, Southeast Asia, Korea and Taiwan. Tō-a dōbunkai and Kanji tōitsukai need to be read within this imperial context. This adoption of modern wakan konkōbun, that is Chinese characters integrated with Japanese, can be seen as the writing system best suited for Japan-centric Pan-Asianism, and, in turn, for colonialism. Under Japanese colonial rule, Korean language takes on a symbolic role in retaining its national identity. Using Chinese was regarded as foreign to vernacular Korean since the nation's essence is captured in its national language and its letters. Retaining Chinese in Japan was an imperial strategy; abolishing Chinese in Korea was a resistance against that violence. Thus Japanese colonial rule intensified the debate between those who favoured gukhanmun style and those who advocated pure hangul. 
To conclude, I will observe three main issues related to the state of script in the Chinese scriptworld. They are directly relevant to the linguistic reality of South Korea but are also applicable to all East Asian countries. First is the issue about coining new words. In the transition into modernity and the western world order, newly-coined words are a continuing necessity, which has not changed in the twenty-first century. Western technology continues to dominate and necessitate a continual flow of western concepts. In the twentieth century, both North and South Korea rapidly shed their Chinese, to the point that now the situation appears irrevocable. Among the challenges that this has brought is how to create new words. In an ideographic culture, coining new words without recourse to Chinese is extremely difficult and unsatisfactory. In the early twentieth century, most of the loanwords came from Japan and were in ideographic Chinese inflected by the Japanese vernacular. The words are generally still used today. This is not a satisfactory linguistic settlement. Resorting to existing loan words with Japanese roots is not ideal but without ideographic Chinese we have lost the capacity to create new words.

Second, there is the issue of English. In pre-modern East Asia, Chinese was the language of the empire, but English may be called today's global imperial language. There was a proposal in South Korea to make English an additional official language, which was met with public outrage. But paradoxically, the learning of English is sweeping through South Korean society like a forest fire. Here a distinction needs to be made between the two imperial languages. Even though Korea was diglossic for thousands of years and Chinese was a universal script of culture and learning in East Asia, there remained ample space for the development of the vernacular because of the ideographic nature of Chinese writing. English does not offer comparable autonomy. The ascendency of English is reducing the space for vernacular Korean. This is a grave concern for today's intellectuals.

The third issue pertains to the standardization of Chinese script. As Chinese loses its standing as the universal lettering in East Asia, there is no longer a means for intra-regional communication. In the future, we may well face a situation when we will read each other's literatures in English translation. Though for centuries spoken languages divided this region, we had a common literary base. But in the twentieth century, the writing system itself has diverged. We currently have different states officially using different types of Chinese scripts: the Chinese jianziti (简字体: simplified Chinese), the Japanese ryakutai (略体) and the Korean and Taiwanese beonchae/fanti (繁體: unsimplified Chinese). This modern phenomenon may be redirected in future. 
The Chinese scriptworld is an historic rather than a current entity. But the historic legacy calls out for recognition. Recognition is key to dialogue and interchange between East Asian nations. Though East Asian literature is separated by the borders of nations and national languages today, they emerged from the ruins of a once cohesive Chinese scriptworld. For a renewal of an East Asian literature, the borders of nations and languages must once again be crossed. To pave the path of reconnection, it is imperative for East Asian intellectuals to reclaim our common heritage of communication and exchange.

\section{Works Cited}

Choi, Hae. "Donginjimunseo 東人之文序" ("Preface to Easterner's writings"). Jolgocheonbaek 拙稿千百 (The Thousands of My Manuscript), vol. 1-2. Trans. Jaegi Choi. Seoul: Institute for Translation of Korean Classics, 2006.

Hong, Daeyong. Damheonseo 湛軒書 (Collection of Damheon's Works), vol. 1-7. Kyeongseong: Sinjoseonsa, 1939.

Hwang, Hyeon. Maecheonyarok 梅泉野錄 (Unofficial Records of Maecheon), vol. 1-3. Trans. Lim, HyungTaek et al. Seoul: Munhakgwajiseongsa, 2005.

Isawa, Shuji. “Preface.” Dōbun shin jiten 同文新字典 (New Dictionary of Shared Letters). Tokyo: Kanji tōitsukai, 1909.

Ju, Sigyeong. Gukeomunjeoneumhak 國語文典音學 (Grammar and Phonetics of Korean). Seoul: Bakmunseogwan, 1908.

Kaneko, Kentaro. Dōbun shin jiten 同文新字典 (New Dictionary of Shared Letters). Tokyo: Tō-a dōbunkai, 1908.

Koyasu, Nobukuni. "Hanja and the Recognition of Own Language in Modern Japan." Daedong Munhwa Yeongu 大東文化研究 (The Journal of Eastern Studies) 58, 2007.

Lim, HyungTaek. Silsagusieui Hangukhak 실사구시의 한국학 (Korean Studies for Seeking Truth from Facts). Seoul: Changbi, 2000.

Lim, HyungTaek. Munmyeongeusikgwa Silhak 문명의식과 실학 (Silhak and the Recognition of Civilization). Seoul: Dolbaegae, 2009.

Lim, HyungTaek. "Isipsegi Jeonhueui munmyeongdamrongwa Eomunjilseo 20 세기전 후의 문명담론과 어문질서" ("Discourses on Civilization and Literary Orders Around 2oth Century"). Eomun yeongu 語文研究 (The Journal of Korean Language and Literature) 162, 2014.

Lim, HyungTaek. "Hanmunsegyeeui Jungsimgwa Jubyeon 한문세계의 중심과 주변" ("Center and Periphery of the World of Chinese letters"). Daedong Munhwa Yeongu (The Journal of Eastern Studies) 90, 2015.

Saito, Mareshi. Kanbunmyaku to nihon kindai 漢文脈と近代日本 (The Contexts of Chinese Letters and Modern Japan). Tokyo: Kadokawa, 2014. 
Tsuneya, Seihuku. Chōsen kaikashi 朝鮮開化史 (History of Korean Modernization). Tokyo: Tō-a dōbunkai, 1904.

Takeuchi, Yoshimi. Nihon to Asia 日本とアジア (Japan and Asia). Trans. Seo Gwangdeok and Baek Jiun. Seoul: Somyong, 2004.

Yi, Yeon-suk. Kokugo toiu shisō 國語という思想 (National Language as a Thought). Tokyo: Iwanami Shoten, 1996. 